\title{
Islamic Universities Facing Disruptive Era: Implication for Management Change
}

\author{
N Kholis ${ }^{1}$ \\ Universitas Islam Negeri (UIN) Sunan Ampel Surabaya, Jawa Timur, Indonesia ${ }^{1}$ \\ \{nurkholis@uinsby.ac.id $\left.{ }^{1}\right\}$
}

\begin{abstract}
New disruptive online-based innovations have shaken and even replaced many incumbent business practices. They also disrupted many university operations and their effects would be stronger in the future. This conceptual paper aims at discussing ideas that Islamic universities in Indonesia may use for their survival and continuous development in the era of disruption. This study uses extant literature pertaining to the topic studied. Data were analyzed inductively to present synthesized information regarding the strategies useful for Islamic universities in facing disruptive era. The study concludes that Islamic universities should undergo fundamental changes in order to meet the requirement of a disruptive era. This includes, first, a paradigm shift in the system operation from hierarchical and rigid systems to agile, adaptive, and innovative systems. Second, the expansion and diversity of program offerings based on ICT should be afforded. Third, the curriculum model should seek to build a proper human value: balancing hard and soft skills. Fourth, the learning model should be shifted from 'productive' to 'generative' one. Fifth, for achieving generative learning, student-centered learning approaches, e.g., problem-based learning should be implemented. A further empirical study is needed to map out the readiness of Islamic universities in adapting to the era of disruption.
\end{abstract}

Keywords: Islamic Universities, Disruptive Era, Management Change

\section{Introduction}

Universities are the highest-level educational institutions that prepare quality human resources to engage in society adaptively and meaningfully. Three main functions of universities in Indonesia include the formation of national character; developing innovative, responsive, creative, skilled, competitive, and cooperative human resources; and the development of humanist-based science and technology [1]. These normative functions have long been carried out through education, research and community service activities and have produced graduates who are able to contribute to the social development.

However, the world has experienced remarkable changes along with the changing times, especially after the turn of the 21 st century marked by the rapid invention of Information and Communication Technology (ICT) [2], which has then resulted in globalization. Studies are carried out to disclose the positive or negative impacts of globalization on all sectors of life, e.g., economy, politics, environment, health, and education [3] and even the value and belief systems [4]. Globalization particularly provides challenges for Indonesian universities that is 
the greater demand to produce graduates with qualifications that are compatible and competitive globally [5].

Nearly a decade after the onset of the 21 st century, the global community was shocked by the coming of the Industrial Revolution 4.0 era echoed publicly in 2011, and its accompanying effect called the disruptive era, which then poses a real challenge to universities including Islamic higher education institutions (in this paper they are called Islamic universities or IUs) in Indonesia. This conceptual article is aimed at exploring and discussing the nature of disruptive era and its implications for universities; and then, proposing some strategies that IUs may use to deal with it. Despite the fact that the strategies are worth to put into trial, the IUs may still face difficulty to implement them.

\section{Method}

As a conceptual paper, this article seeks to present an explanation about the topic, connect various disciplines, provide insight across perspectives, and expand understanding [6]. In order to discuss the topics, the writer used available and useful secondary data in the forms of books, journal articles, and opinions published online pertinent to the current discussion. To date, the literature relating to the topic is scarce as this issue emerges quite recently. The data collected was analyzed using the inductive approach, that is the observed data were systematically synthesized to allow for drawing a conclusion regarding the topic discussed.

\section{Result and Discussion}

\section{Disruptive era: what and how?}

The disruptive era emerges as a result of the Industrial Revolution (IR) 4.0 based on ICT (internet-based). The IR 4.0 emerged as a result of the extraordinary development of robotics technology, machine learning \& artificial intelligence (AI), the Internet of Things (IoT), and $3 \mathrm{D}$ printing. The focus of IR 4.0 is on collaboration, interconnectivity, and data disclosure which enable collaboration not only between humans but also between machines[7]. In IR 4.0, machines and factories are interconnected, data are massively exchanged, work is performed collaboratively, and independent decisions are made collectively. This has changed a lot of things: how factories operate, how business relationships are conducted, and how consumers shop for their needs. IR 4.0 offers time and resource efficiency, cost savings, increased revenue, agility, and innovation for the industry.IR 4.0 affects disruption in the ways of work that has long been done. Many established practices are replaced by new innovations based on disruptive (online) technology [8]. The era of disruption takes place when a new innovation enters the market and creates a disruption effect strong enough to change the previous market structures. Clayton Christensen [9] proposes a theory of disruptive innovation which states that the end of series in the hands of innovators who create something new by meeting the contemporary needs through simpler, more affordable, and more accessible mechanisms.

The effects of disruption are observable in Indonesia, for example, online taxis replaces base taxis, online marketplaces disrupts various base markets that have significantly changed the buying and selling trends for some products[10]. More examples include the presence of desktop publishing disrupting the incumbent publishing business, the presence of digital camera innovations disrupting the film-camera industry, and online payment systems replacing many direct payments models whereby reducing the production of cash register 
machines. Some are "disrupted" and then destroyed; some are distracted but finally remain to exist because they clean up the mass.

This era of disruption was initially affecting the business world and gradually gave a real impact on the world of education[11]. Some developed countries, which have been the centers of the development of science and technology, are facing changes that are speeding up unbearably and are not easily overcome with existing instruments today [12]. Christensen and Eyring [13] argued that universities had experienced the effects of disruptive technology, which require them to rethink the traditional college model because otherwise, they would face huge financial risks. Because of this innovative technology, Harden [14] predicts that there would be an enlarged free access to tertiary level education, the defunct of physical campuses, the lessening of many teaching jobs, the increasing irrelevance of a bachelor's degree; and a significant increase in the number of students for campuses with an online program offering. This disruption will likely affect the universities in Indonesia including the IUs. Thus, it must be well anticipated so that they can foresee new opportunities in the future.

\subsection{Some strategies}

The IUs need to restructure their management system comprehensively so that they could compete and survive in this disruption climate. The following are some strategic ideas that may be used as bases for IU development.

\subsubsection{Paradigm Shift}

Michael Chavez [15] argues that many businesses fail to face the digital trend because they are built on the assumptions of a linear world, arranged in a hierarchically strict and rigid manner; but this rigid structure should be abandoned as today's context demands agility, adaptability, and innovation. This statement can be applied to the campus paradigm during this era of disruption. The campus must be given free space to create and innovate in managing its resources to offer academic products to the desired market segment; leaned towards an entrepreneur university. Kaplan University Partners [16] conducted a survey of parents' expectations of universities (reflecting their market demands) and found, among them, two important things, namely more affordable costs and providing marketable skills without leaving the development of social skills and critical thinking. Innovation means discovery which is applied and brought to market. Successful innovation usually requires an innovative business model and demands innovative product offerings [17]. This requires a change of academic freedom policy in a very broad sense. There is no need for a formal licensing of whether or not an academic product is opened as a service to the community. The feasibility of opening an academic service is determined primarily by the market's readiness to "buy it" and whether it will benefit the university operations.

\subsubsection{Expansion of program offering}

Social and economic systems are increasingly dynamic in this era of disruption. In the past, almost everyone thought of sending their children to universities to get a good job. Now, more and more people want to continue their higher education without having to interfere with their daily activities, such as work. Furthermore, more high school graduates directly want to get a job while later increasing their professionalism through college. Many of them don't go to university to get a job, but they go to a job (go Pro First) to, then, pursue an academic degree. This orientation shift will be the biggest disruption for tertiary educations many high school 
graduates will not enroll directly to the university, but will work while studying or work first and then study.

The internet-based distance learning such as Open Educational Resources (OER) managed through EDUCAUSE offers online sources of skills and expertise at affordable prices and even free [18]. The Massive Open Online Course (MOOC) has been run by several prominent higher educations in America over the past decade with the success of enrolling a significant number of students [19]. Since its introduction in 2006, MOOC has proven to be an ideal learning solution for generations raised in the internet era and for those who are already in the workforce who need time flexibility and online collaboration outside the classroom. These institutions find that their growth is not limited by the size of their campuses, the number of satellite campuses or the availability of qualified applicants in their markets. Their market now is all over the world.

In Indonesia, this model has to some extent been implemented, for example, Teacher Professional Education (PPG) through an online learning system. In 2018, a total of 26,358 teachers under the Ministry of Education and Culture (MoEC) took part in the PPG managed by the MoRTHE, with a Hybrid Learning pattern, namely through a three-month online learning followed by a five-week face-to-face workshop, and finally followed by a three-week field experience program (PPL) [20].A similar model has also been implemented by IUs under the Ministry of Religious Affairs (MoRA). In 2019, a total of 6,800 (6,000 religious subject teachers and 800 general subject teachers) in madrassas followed the PPG online model [21]. At the school level, "ruangguru," a digital startup company engaged in online education since its founding in 2014 has had more than 6 million users and has managed more than 150,000 teachers who offer services in more than 100 subject areas. In addition, Ruangguru offers subscription learning videos, private tutoring markets, on-demand tutoring services, online test tryouts, etc. [22].

These three educational models offer flexible learning time and are relatively affordable. This phenomenon is predicted to increase in the future and requires a disruptive response by Higher Education (HE) including IUs. Thus, IUs may consider expanding their program offerings based on ICT both in the form of study programs or specific skills needed by prospective users.

\subsubsection{Curriculum Model}

Higher education has long assumed an important role as a producer of skilled human resources. Moreover, to face the demographic bonus, HE plays a very critical role in preparing graduates with the knowledge and skills needed in this era [5]. But, the range of skills needed by Industry 4.0 is no longer the same as before. In this sophisticated era, humans and smart machines will co-exist at work. The implication is not only on business but on the wider scale of society. Jack Ma in the 2018 World Economic Forum delivered two important statements relating to education that can be used as a guide to the curriculum model is facing disruption. Ma said, "if we don't change the way we teach, then in 30 years we will face problems." [23]. Ma also said, "everything we teach (curriculum) must make people different from machines" [24]. Jack Ma stated that what makes us different from machines is values, belief, independent thinking, teamwork, and caring for others, strengthening soft skills.

The Indonesian government has integrated quite a large portion of the development of soft skills for HE graduates [25]. These skills can be categorized into two main groups namely intrapersonal skills and interpersonal skills. Intrapersonal skills include self-awareness (selfconfidence, self-assessment, trait and preference, emotional awareness) and self-skills 
(improvement, self-control, trust, worthiness, time management, proactivity, conscience). Whereas interpersonal skills include social awareness (political awareness, developing others, leveraging diversity, service orientation, empathy) and social skills (leadership, influence, communication, conflict management, cooperation, teamwork, and synergy) [26]-[28].

A survey of CEOs in China, Britain, America, and India found the skills needed to work in the coming decade, which include problem-solving, adaptability, collaboration, leadership, creativity and innovation [29]. While the World Economic Forum [30] released 10 soft skills that are highly needed by the world of work in 2020: complex problem solving, critical thinking, creativity, people management, coordinating with others, emotional intelligence, judgment and decision making, service orientation, negotiation, and cognitive flexibility. It is predicted that the world of work in 2025 will require five main soft skills: social intelligence skills, cross-cultural competency skills, new media literacy skills, virtual collaboration skills, and self-direction skills [31]. In essence, the IUs must prepare excellent students and more competitive graduates by optimizing four literacies: (1) basic literacy (reading, writing, arithmetic skills); (2) data literacy (the ability to read, analyze and use digital information; (3) technological literacy (understanding how to work and technology applications); and (4) human literacy (developing cognitive capacity in the form of higher-order thinking skills, critical and systemic thinking [32]. Put it simply, the IUs need to strengthen their curriculum model to offer a balance between hard and soft skills.

\subsubsection{Generative Learning}

The HE individuals and organizations need to shift from 'productive' to 'generative' learning model. O'Driscoll and Kapp [33], [34] explain that "productive learning serves to maintain the status quo by conveying what is known, while generative learning not only absorbs known information but also generates new information while overcoming unexpected opportunities or challenges. In economic terms, productive learning focuses on efficiency and productivity, while generative learning focuses on innovation and growth." Much traditional learning has focused on technical issues and productive learning. However, in this very dynamic era, we must move towards generative learning and adopt an adaptive approach. Adaptive approaches are needed to solve problems for which there are no simple solutions and are designed to overcome new problems that require new ways [35].

The Corporate Research Forum details individual and organizational level learning that characterize productive and adaptive approaches [36]. On the individual / productive level, learning is focused on providing assistance to individuals to improve performance according to their role, for example, sales training. In contrast, in the individual / generative area, learning is done to help individuals learn key skills that enable them to generate new ideas or strategies, for example teaching critical thinking. The organizational/productive level includes working in teams to improve efficiency or productivity in existing businesses, for example, management training. On the other hand, generative organizations include the use of team or organizational collective wisdom to produce new solutions, identify new markets, and challenge existing assumptions, such as holding group work to identify ten major disruptive innovations that emerge in the market and examine how they can influence the existing business models.

The core of this new paradigm is that organizations must be agile, learn continuously from successful and unsuccessful experiments, and share information learned with relevant parts of the organization to make learning a source of continuous improvement. 


\subsubsection{The principle of learning}

Deans for Impact [37] formulated five learning principles to be applied by lecturers in the era of disruption. First, lecturers apply a student-centered learning approach such as small group discussion, discovery learning, project-based learning, and problem-based learning[38]. The one-way teaching model is considered ineffective because students can find information easily due to diverse sources of information both print and digital and the availability of supporting technologies. Today's students who are, on average, millennials are always-connected, socialsavvy, app-happy, and smartphone-dependent. With this, there is a high chance for them to become self-learners. With a student-centered method, the smartphone can become a backbone of active, interactive, creative and collaborative learning. This requires lecturers to master and always be up to date with ICT applicable in education practices.

Second, lecturers provide essential material or tasks, with clear goals, and which can be well captured by students. Learning assignments with a research approach can be applied to give students experience in applying research models and simulations to solve problems directly. Third, lecturers search for information about the impact of student learning. Teaching methods and contents that lack a positive impact must be replaced with more relevant materials and methodologies. This means that in addition to based on existing theories, learning materials must touch on real and current aspects that can be digested by students; the essence of a contextual learning approach.

Fourth, lecturers invite students to make reflections and provide input/advice to lecturers to develop better learning techniques. Lecturers also have to get used to giving feedback on student assignments, so they know at what point they have to correct mistakes or maintain what is already good. This can reduce student misunderstanding of the knowledge and skills learned[39]. Fifth, lecturers apply a mindset that makes the student expert after leaving the class. Lecturers are a mirror for students, so they need to present as an exemplary expert figure before students. Using this model of mental expertise will, directly and indirectly, raise the standard of learning and education.

\section{Conclusion}

The era of disruption as an impact of the Industrial Revolution 4.0 has surfaced, shaken, and replaced long-established systems and practices. Universities that maintain the traditional model will run into a risky business as they will be abandoned by their customers. Thus, universities including the Islamic ones need to make fundamental and overall system changes. The campus must be built on the assumption of a non-linear world, arranged with flexibly and continuous learning because the present era demands agility, adaptability, and innovation. They must continuously create and innovate in managing their resources to offer academic products to the desired market segment, to become an entrepreneur university. One of the innovations is to expand its program offerings based on ICT (online-based)needed by prospective users. The curriculum designed must produce graduates with the knowledge and skills needed in this era, which combines hard skills and especially soft skills. The learning systems must emphasize not only reproducing things that have been known before (productive) but producing new things that have not been in existence (generative). Generative learning will enable graduates to play a wider role in life and the world of work; an adaptive ability. Lecturers' teaching approaches must refer to the principles of contemporary learning and adopt a new tradition of student learning that increasingly relies on ICT and optimize materials that have a real impact on students. These efforts will succeed with strong support 
from university leaders, by developing innovative strategies and building an adaptive learning organization.

\section{References}

[1] Indonesian Govt., "Undang-Undang Republik Indonesia Nomor 12 Tahun 2012 Tentang Pendidikan Tinggi." 2012.

[2] R. E. Indrajit, Teknologi Informasi dan Perguruan Tinggi: Menjawab Tantangan Pendidikan Abad ke-21. Online: APTIKOM, 2011.

[3] F. M. Hamdi, "The Impact of Globalization in the Developing Countries," Developing Country Studies, vol. 3, no. 11, p. 4, 2013.

[4] H. A. Wani, "Impact of Globalization on World Culture," Research J. Humanities and Social Sciences, vol. 2, no. 2, pp. 33-39, 2011.

[5] Minister MoRTHE, "Lulusan Perguruan Tinggi Harus Unggul Dalam Persaingan Global," Kementerian Riset, Teknologi, Dan Pendidikan Tinggi Republik Indonesia, 25Mar-2018. [Online]. Available: https://ristekdikti.go.id/kabar/lulusan-perguruan-tinggiharus-unggul-dalam-persaingan-global/9. [Accessed: 17-Aug-2019].

[6] L. L. Gilson and C. B. Goldberg, "Editors' Comment: So, What Is a Conceptual Paper?," Group \& Organization Management, vol. 40, no. 2, pp. 127-130, Apr. 2015.

[7] A. Rojko, "Industry 4.0 Concept: Background and Overview," International Journal of Interactive Mobile Technologies (iJIM), vol. 11, no. 5, p. 77, Jul. 2017.

[8] M. Flavin, "Disruptive technologies in higher education," Research in Learning Technology, vol. 20, no. sup1, p. 19184, Aug. 2012.

[9] C. M. Christensen, The Innovator's Dilemma: When New Technologies Cause Great Firms to Fail. Boston, MA.: Harvard Business School Press, 1997.

[10] S. Liani, "Mengenal Era Disrupsi (Disruption Era) dan Strategi Menghadapinya," ruang guru, 24-Sep-2018. .

[11] M. Gardner, "Education in the Age of Disruption," Monash University, 08-Jun-2016. [Online]. Available: https://www.monash.edu/about/structure/senior-staff/vicechancellor/profile/vice-chancellors-speeches/education-in-the-age-of-disruption. [Accessed: 05-Jun-2019].

[12] M. Oey-Gardiner, S. I. Rahayu, M. A. Abdullah, Y. Darma, T. Dartanto, and C. D. Aruan, Era Disrupsi: Peluang dan Tantangan Pendidikan Tinggi Indonesia, 2nd ed. Jakarta: Akademi Ilmu Pengetahuan Indonesia, 2017.

[13] C. M. Christensen and H. J. Eyring, The innovative university: changing the DNA of higher education from the inside out, 1st ed. San Francisco: Jossey-Bass, 2011.

[14] N. Harden, "The End of the University as We Know It," The American Interest, 11Dec-2012.

[15] M. Chavez, "Unlocking Agility Through Purpose," Forbes, Jun-2018. [Online]. Available: https://www.forbes.com/sites/michaelchavez/2018/06/29/unlocking-agilitythrough-purpose/\#3f8086f378bf.

[16] Kaplan University Partners, "Destination College: Exploring New Routes to Success," Apr. 2019.

[17] P. Li, "Innovation in higher education: the effectiveness of disruptive technology in elearning," Haaga-Helia University of Applied Sciences, Finland, 2017.

[18] Educause, "Open Educational Resources (OER)," Aug-2019. [Online]. Available: https://library.educause.edu/topics/teaching-and-learning/open-educational-resourcesoer. 
[19] P. Friederichsen, "How Higher Education Brands Can Face Disruption," Aug-2018. [Online]. Available: https://www.brandingstrategyinsider.com/2018/08/how-highereducation-brands-can-face-disruption.html\#.XWa9AXsxXIV.

[20] Minister MoEC, "Press Release Penyelenggaraan PPG dalam Jabatan Tahun 2018," Direktorat Pembinaan Guru Pendidikan Menengah dan Pendidikan Khusus, 06-Jul2018. [Online]. Available: http://pgdikmen.kemdikbud.go.id/press-releasepenyelenggaraan-pendidikan-profesi-guru-ppg-dalam-jabatan-tahun-2018.

[21] M. Abdul Muiz, "138 ribu guru madrasah akan ikuti seleksi peserta PPG 2019," Berita Biro Humas Data dan Informasi Kementerian Agama, Mei-2019. [Online]. Available: https://kemenag.go.id.

[22] ruangguru.com, "Tentang Ruangguru," Aug-2019. [Online]. Available: https://ruangguru.com/general/about.

[23] World Economic Forum, Jack Ma: "If we do not change the way we teach, thirty years from now we will be in trouble." Youtube, 2018.

[24] World Economic Forum, Jack Ma: "Everything we teach should be different from machines." Youtube, 2018.

[25] Indonesian Govt, "Peraturan Presiden No 8 Tahun 2012 Tentang Kerangka Kualifikasi Nasional Indonesia." 2012.

[26] A. H. Muhmin, "Pentingnya Pengembangan Soft Skills Mahasiswa Di Perguruan Tinggi," Forum Ilmiah, vol. 15, no. 2, p. 9, 2018.

[27] T. K. Ngang, "Soft Skills Integrated in Sustainable Higher Education," Journal of Modern Education Review, vol. 1, no. 2, pp. 99-110, Dec. 2011.

[28] Sutrisno and A. Karjanto, "Peningkatan Soft Skill Dan Prestasi Belajar Mahasiswa Pada Matakuliah Metodologi Penelitian Melalui Pembelajaran Model Learning Community," TEKNOLOGI DAN KEJURUAN, vol. 37, no. 1, pp. 25-38, Feb. 2014.

[29] PwC, Workforce of the future - The competing forces shaping 2030. 2018.

[30] World Education Forum, The Future of Jobs Employment, Skills and Workforce Strategy for the Fourth Industrial Revolution. Geneva Switzerland, 2016.

[31] Getmaster, "5 Pioneering Skills You'll Need By 2025," Nov-2016. .

[32] Humas Unimus, "Pembelajaran Kurikulum KKNI \& SNDikti Tingkatkan Lulusan Berkualitas," 12-Apr-2019. [Online]. Available: http://unimus.ac.id/?p=35149.

[33] T. O’Driscoll, "Productive vs. Generative Learning," Sep-2017. [Online]. Available: https://trainingmag.com/trgmag-article/productive-vs-generative-learning.

[34] T. O'Driscoll and K. M. Kapp, Learning in 3-D: Adding a New Dimension to Enterprise Learning and Collaboration. San Francisco, CA: Pfeiffer, 2010.

[35] C. Douglas, "What should learning look like in an era of disruptive change?," Corporate Research Forum, 20-Dec-2017. .

[36] G. Pillans, Learning - The Foundation for Agility and Sustainable Performance. London, UK: Corporate Research Forum, 2017.

[37] Deans for Impact, Practice with Purpose: The Emerging Science of Teacher Expertise. Austin, TX: Deans for Impact, 2016.

[38] N. Kholis, "The Importance of Problem Based Learning in Islamic Higher Education," Nadwa, vol. 12, no. 2, p. 335, Jan. 2019.

[39] P. Ramsden, Learning to teach in higher education, 2nd ed. London; New York: RoutledgeFalmer, 2003. 